\title{
Structural and Functional Characterization of the Human T Lymphocyte Receptor for Insulin-like Growth Factor I In Vitro
}

\author{
Victor F. Tapson, Marianne Boni-Schnetzler, Paul F. Pilch, David M. Center, and Jeffrey S. Berman \\ Pulmonary Center and Department of Biochemistry, Boston University School of Medicine, Boston, Massachusetts 02118
}

\begin{abstract}
Growth factor receptors for T lymphocytes, such as interleukin 2 and insulin, are present on activated but not resting $T$ lymphocytes. We sought to determine if insulin-like growth factor I (IGF-I) could act as a growth factor for human $T$ cells and to characterize its receptor on resting and activated cells. Recombinant IGF-I induced two separate functions. It was chemotactic for and increased incorporation of tritiated thymidine into both unactivated (resting) and mitogen-activated $T$ cells. High-affinity ${ }^{125}$ I-IGF-I binding to human $T$ cells was saturable with an apparent $K_{d}$ of $1.2 \pm .6 \times 10^{-10} \mathrm{M}$ for binding to activated $T$ cells and $1.2 \pm .9 \times 10^{-10}$ for unactivated $T$ cells. The calculated binding for activated cells was $330 \pm 90$ and for resting cells $45 \pm 9$ high-affinity receptor sites per cell. Affinity cross-linking of ${ }^{125}$ I-IGF-I to resting or activated $T$ cells revealed a radioligand-receptor complex of $360,000 \mathrm{~mol}$ wt when analyzed by SDS-PAGE without reduction and complexes of 270,000 and 135,000 mol wt upon reduction; prior incubation with excess unlabeled IGF-I prevented formation of the ${ }^{125} I$ IGF-I receptor complex. Our data suggest that both resting and activated $T$ lymphocytes bear functional IGF-I receptors similar to those found in other tissues. These receptors may mediate $T$ cell growth and chemotaxis.
\end{abstract}

\section{Introduction}

Insulin-like growth factor I (IGF-I) ${ }^{1}$ is a polypeptide with insulin-like chemical structure and biologic properties (1). It circulates as a high molecular weight complex bound to a specific carrier protein. IGF-I has been shown to be identical to somatomedin $\dot{C}$ and appears to be synthesized in many mammalian tissues (2-6). Receptors for IGF-I have been identified in numerous tissues including placenta (7), fibroblasts (8), neuronal tissue (9), skeletal muscle (10), Leydig cells (11), mononuclear cells (12), and B lymphocytes (13). In vivo, IGF-I is considered to be primarily a growth hormone-dependent circulating growth factor with an important effect upon skeletal growth (1), while in high doses, IGF-I may function to regulate acute metabolic responses (14).

Address reprint requests to Dr. Tapson, Pulmonary Center, Boston University School of Medicine, 80 East Concord Street, K-603, Boston, MA 02118.

Received for publication 3 September 1987 and in revised form 2 February 1988.

1. Abbreviations used in this paper: hpf, high-power field; IGF-I, insulin-like growth factor I; M199, Medium 199; T, thymidine.

J. Clin. Invest.

(c) The American Society for Clinical Investigation, Inc.

$0021-9738 / 88 / 09 / 0950 / 08 \quad \$ 2.00$

Volume 82, September 1988, 950-957
Accumulation of recirculating $\mathrm{T}$ lymphocytes at tissue sites is thought to occur by recruitment and subsequent local proliferation. The major means by which recruitment may occur is directed migration or chemotaxis (15). In fact, several growth factors have been shown to be chemotactic for human $\mathrm{T}$ cells, including interleukin 1 (IL-1) $(16,17)$, interleukin 2 (IL-2) (18), antigen (19), and insulin (20), suggesting that such growth factors might be capable of both steps in the accumulation of $T$ lymphocytes: chemotaxis, and subsequent proliferation.

Insulin receptors are found on activated but not unact1vated (resting) $\mathrm{T}$ cells (21-23). Recently, we found insulin to be chemotactic for mitogen-activated human $\mathrm{T}$ lymphocytes in doses consistent with action on high-affinity insulin receptors (20). This effect was not seen with resting $T$ cells unless very high doses of insulin were used, consistent with the hypothesis that insulin was acting via lower-affinity IGF-I receptors. It has been demonstrated that insulin may compete to occupy IGF-I receptors $(13,24)$. Because of the similarities between insulin and IGF-I and their receptors, we evaluated the chemotactic and proliferative responses of $T$ lymphocytes to IGF-I. We determined IGF-I to be chemotactic for resting and activated $\mathrm{T}$ cells in doses consistent with action on highaffinity IGF-I receptors. IGF-I stimulated increased tritiated thymidine $\left(\left[{ }^{3} \mathrm{H}\right] \mathrm{T}\right)$ incorporation into resting and activated $\mathrm{T}$ cells in a standard proliferation assay. We also characterized the IGF-I receptor on both resting and activated $T$ cells employing binding assays and affinity cross-linking studies.

\section{Methods}

Isolation and purification of $T$ lymphocytes. Human peripheral blood mononuclear cells (PBMC) were isolated from the heparinized venous blood of healthy human volunteers by density centrifugation on Ficoll-Paque (Pharmacia Fine Chemicals, Piscataway, NJ). Cells were recovered from the Ficoll-medium interface, washed three times in medium 199 (M199, Microbiological Associates, Bethesda, MD), supplemented with $100 \mathrm{U} / \mathrm{ml}$ penicillin and $100 \mu \mathrm{g} / \mathrm{ml}$ of streptomycin and $25 \mathrm{mM}$ Hepes buffer (M199-HPS). Blood monocytes were removed by suspending $75 \times 10^{6} \mathrm{PBMC}$ in $15 \mathrm{ml} \mathrm{M} 199-\mathrm{HPS}$ in sterile glass petri dishes for $1-2 \mathrm{~h}$ at $37^{\circ} \mathrm{C}$. After incubation, the plates were washed five times with warmed $\left(37^{\circ} \mathrm{C}\right)$ media and the monocyte-depleted supernatant recovered. Nylon wool-nonadherent human $T$ cell-enriched populations were prepared by a modification of the method of Julius et al. (25). $3 \mathrm{~g}$ of prewashed sterilized nylon wool (Fenwal Laboratories, Deerfield, IL) were placed in a 30-ml syringe. The nylon wool column was soaked with M199-HPS with $0.4 \%$ bovine serum albumin (BSA) (Miles Laboratories, Inc., Elkhart, IN). Monocyte-depleted cells were then applied to the column and incubated for 1 h. After incubation, the nonadherent cells were eluted with media at a flow of $1 \mathrm{ml} / \mathrm{min} .25-40 \%$ of the cells were recovered in the eluate of which $>95 \%$ were CD3+ as assessed by fluoroscein isothiocyanate-labeled (FITC) monoclonal antibody (Leu-4, Becton, Dickinson \& Co., Mountain View, $C \dot{A})$ and flow cytometric analysis with the fluorescence activated cell sorter (Becton, Dickinson \& Co. FACS 440). Cell viability, checked by employing exclusion of trypan blue dye (Gibco, Grand Island, NY) was routinely $>90 \%$. 
T lymphocyte subsets. For some chemotaxis experiments, human $\mathrm{T}$ lymphocytes were further separated into $\mathrm{CD}^{+}$or $\mathrm{CD}^{+}$subsetenriched populations by negative selection utilizing a modified "panning" technique. Magnetic beads (BioMag, Advanced Magnetics, Cambridge, MA) that were conjugated to ovine polyclonal antibody to FITC were utilized. $100 \mu \mathrm{l}$ of commercially obtained FITC-conjugated monoclonal antibody to CD4 or CD8 (OKT4 or OKT8, Ortho Diagnostics, Raritan, $\mathrm{NJ}$ ) was added to $\mathrm{T}$ lymphocytes and were incubated on ice for $20 \mathrm{~min}$ and then washed three times in iced M199. $5 \mathrm{ml}$ of bead slurry was washed twice in M199, mixed with cells, and then incubated at $37^{\circ} \mathrm{C}$ for $30 \mathrm{~min}$. The reaction flask was taped to a strong magnet, and after $5 \mathrm{~min}$ the nonadherent cells were decanted. Decanted cells were tested for adequacy of depletion by assessing staining for the depleted CD marker with the FACS; the procedure was repeated if the depleted CD marker stained $>5 \%$ of the cells.

Cell migration. A modification of the Boyden chamber technique (26) was utilized to assess T lymphocyte chemoattractant activity in response to recombinant IGF I (AmGen Biologicals, Thousand Oaks, CA). $50 \mu \mathrm{l}$ of a T lymphocyte suspension containing $10 \times 10^{6} \mathrm{cells} / \mathrm{ml}$ of M199-HPS with $0.4 \%$ BSA was placed in the upper compartment of 48-well microchemotactic chambers (Bio-Rad Laboratories, Rockville Center, NY) separated by $8-\mu \mathrm{m}$ pore size nitrocellulose filters (Sartorius Filters, Inc., Cherry Hill, NJ) from $25 \mu$ l of M199-HPS-BSA alone (control) or from IGF-I $\left(10^{-11}\right.$ to $\left.10^{-7} \mathrm{M}\right)$ in M199-HPS-BSA. Except for the absence of IGF-I the control wells were identical in every way. Gradient dependence was determined by the checkerboard technique; IGF-I was placed below the filter only (chemoattractant present with concentration gradient) as well as both above and below (chemoattractant present without concentration gradient). Increased motility over baseline in the former setting represents a chemotactic (gradient-dependent) effect, and in the latter setting a chemokinetic (gradient-independent) effect (27). Migration experiments were carried out for $3 \mathrm{~h}$ at $37^{\circ} \mathrm{C}$ in a $5 \% \mathrm{CO}_{2}$ atmosphere. The filters were fixed, stained, dehydrated, and mounted by using standard histologic methods. Lymphocyte movement was quantitated by counting the total number of cells migrating beyond a fixed distance into the filter. Five highpower fields (hpf) were counted for each of the duplicate wells. Results were calculated as mean cells per high-power field \pm SD. Data were also expressed as mean percentage of control migration. Student's $t$ test was utilized to determine the statistical significance of migration compared with control conditions. A $P$ value of $<0.05$ was considered significant in all chemotaxis experiments.

$\left[{ }^{3} \mathrm{H}\right] \mathrm{T}$ incorporation assay. Phytohemagglutinin (PHA, $2 \mu \mathrm{g} / \mathrm{ml}$; PHA-L, Sigma Chemical Co., St. Louis, MO), interleukin 2 (IL-2, 100 $\mathrm{U} / \mathrm{ml}$ ) (AmGen Biologicals), and IGF-I $\left(10^{-11}\right.$ to $\left.10^{-7} \mathrm{M}\right)$ were added separately or in combination to human T lymphocytes in HL-1 media (containing amino acids, selenium, protein, iron, transferrin, and without insulin) which were then distributed in $200-\mu 1$ aliquots $\left(10^{6}\right.$ cells $/ \mathrm{ml}$ ) into 96 -well round-bottomed culture plates at $37^{\circ} \mathrm{C}$ and $5 \%$ $\mathrm{CO}_{2}$. Controls for resting lymphocytes contained cells and media only; those for activated cells contained PHA and cells with media only. At $48 \mathrm{~h}$, each well was pulsed with $1 \mu \mathrm{Ci}$ of $\left[{ }^{3} \mathrm{H}\right] \mathrm{T}(6.7 \mathrm{Ci} / \mathrm{mmol}$, New England Nuclear Research Products, Boston, MA). At 72 h, the cell nuclei were harvested onto glass fiber filter paper with a Titertek Cell Harvester (Flow Laboratories, Rockville, MD) and counted (counts per minute $\left.\left[{ }^{3} \mathrm{H}\right] \mathrm{T}\right)$ in a Packard Tri-Carb 300 Scintillation Counter (United Technologies Packard, Sterling, VA) for 2 min per sample. The values from quadruplicate wells were averaged and expressed as counts per minute of radioactivity incorporated by $2 \times 10^{5}$ cells after $72 \mathrm{~h}$ of incubation \pm SD. Values were compared with controls and underwent two-way analysis of variance. Cell cycle analysis was also performed; the cells were labeled with propidium-iodide (Sigma Chemical Co.) and analyzed with the FACS.

Competitive binding assays. Conditions for the binding assays performed were similar to those previously utilized for investigation of the IGF-I receptor (9). ${ }^{125} \mathrm{I}-\mathrm{IGF}-\mathrm{I}(2,000 \mu \mathrm{Ci} / \mathrm{mmol}$, Amersham Corp., Arlington Heights, IL) was added in $20-\mu \mathrm{l}$ aliquots $(100,000 \mathrm{cpm} /$ assay) to $20 \mu \mathrm{l}$ of unlabeled ligand $\left(10^{-11}\right.$ to $\left.10^{-7} \mathrm{M}\right)$ or to M199-HPS-
BSA alone. Human T lymphocytes in M199-HPS-BSA were added at $10^{6}$ cells (PHA-activated cells) or $10 \times 10^{6}$ cells (resting cells) per $460-\mu 1$ aliquot yielding a final volume of $500 \mu \mathrm{l}$. After incubation at $15^{\circ} \mathrm{C}$ for $60 \mathrm{~min}$, the tubes were centrifuged for $5 \mathrm{~min}$ in an Eppendorf 5414 centrifuge. The supernatant was removed and the cells remaining were washed. After centrifugation, the cell pellets were obtained by cutting off the tips of the tubes. Bound ${ }^{125}$ I-IGF-I was counted in a Packard Multi-Prias 1 Gamma Counter (United Technologies Packard) and background was subtracted. Binding studies were performed for both resting and 48-h PHA-activated T cells. The counts per minute bound from triplicate samples were averaged. Nonspecific binding was determined as cpm bound in the presence of $10^{-7} \mathrm{M}$ unlabeled IǴF-I and was subtracted from total counts per minute to get specific binding. Binding experiments were performed three times each and were reproducible; representative experiments for both resting and activated cells are shown. In addition a competition assay, comparing insulin and IGF-I binding was performed. Binding assays were each performed at least three times and were reproducible.

Affinity cross-linking of ${ }^{125} I-I G F-I$ to $T$ cells. Cross-linking was performed as described by Pilch and Czech $(28,29)$. Intact human resting and PHA-activated T lymphocytes $\left(25 \times 10^{6}\right.$ cells $)$ were incubated with $10^{-9} \mathrm{M}^{125} \mathrm{I}$-IGF-I $\left(10^{6} \mathrm{cpm} /\right.$ assay), with or without unlabeled IGF-I $\left(10^{-7} \mathrm{M}\right)$, and incubated at room temperature for $30 \mathrm{~min}$; unbound ligand was then removed by centrifugation at $500 \mathrm{~g}$ and discarding the supernatant. Disuccinimidyl suberate (DSS, Pierce Chemical Co., Rockford, IL) was added to yield a final concentration of $0.5 \mathrm{mM}$. After $30 \mathrm{~min}$ the cells were exposed to $100 \mu \mathrm{l}$ of $1.5 \mathrm{M}$ Tris (pH 8.7) while on ice for $15 \mathrm{~min}$ and then (total volume of $1 \mathrm{ml}$ ) were sonicated and centrifuged at $500 \mathrm{~g}$ for $10 \mathrm{~min}$ to remove nuclei. The supernatant was recovered and centrifuged (Eppendorf 5414 centrifuge) and the pellet was then suspended in $100 \mu$ l of phosphate-buffered saline, $\mathrm{pH} 7.4$, plus $100 \mu \mathrm{l}$ of Laemmli sample buffer $(0.5 \mathrm{M}$ Tris- $\mathrm{HCl}, \mathrm{pH} 6.7,2 \%$ sodium dodecyl sulfate, $10 \%$ glycerol and $0.001 \%$ bromophenol blue); reduced samples contained dithiothreitol $(100 \mathrm{mM})$. Samples were boiled for $2 \mathrm{~min}$ and then analyzed by sodium dodecyl sulfate polyacrylamide gel electrophoresis (SDS-PAGE) using a 3-10\% gradient gel. Autoradiograms were developed for $48 \mathrm{~h}$ at $-80^{\circ} \mathrm{C}$, using Kodak X-Omat film (Eastman Kodak Co., Rochester, NY). The molecular weight standards used were myosin $(200,000)$, $\beta$-galactosidase $(116,250)$, phosphorylase B $(97,400)$, BSA $(66,200)$ and hen egg white ovalbumin $(42,699)$ (Bio-Rad Laboratories, Richmond, CA). Affinity cross-linking was performed in the same manner employing HuT 78 cells, a malignant $T$ cell line (30).

\section{Results}

\section{Functional characteristics of IGF-I}

Chemotaxis. Using a modified Boyden chamber technique to evaluate cell motility, we determined the chemoattractant effect of IGF-I on human $T$ lymphocytes. T lymphocytes were incubated for $48 \mathrm{~h}$, with or without PHA $(2 \mu \mathrm{g} / \mathrm{ml})$. As indicated in Fig. 1, unactivated $\mathrm{T}$ cells showed a statistically significant increase in motility when exposed to IGF-I with a peak migration of $24.4 \pm 2.4$ cells/hpf ( $244 \pm 24 \%$ control migration) at $10^{-8} \mathrm{M}$ IGF-I. PHA-activated cells showed a greater increase in motility and a left shift of the dose-response curve peaking at $44.2 \pm 3.2 \mathrm{cells} / \mathrm{hpf}(291 \pm 21 \%$ of control migration $)$ at $10^{-9}$ M. There was no significant difference in baseline random motility between the activated and unactivated cells. Both unactivated and activated cells were depleted to subsets by negative selection utilizing a magnetic panning technique to deplete antibody-coated cells. The chemotactic response to IGF-I of CD4+ and CD8 + T cells were identical, and not different from the response of unseparated T lymphocytes (Fig. 2).

A checkerboard analysis was performed to determine if the effect of IGF-I upon motility was gradient dependent (chemo- 


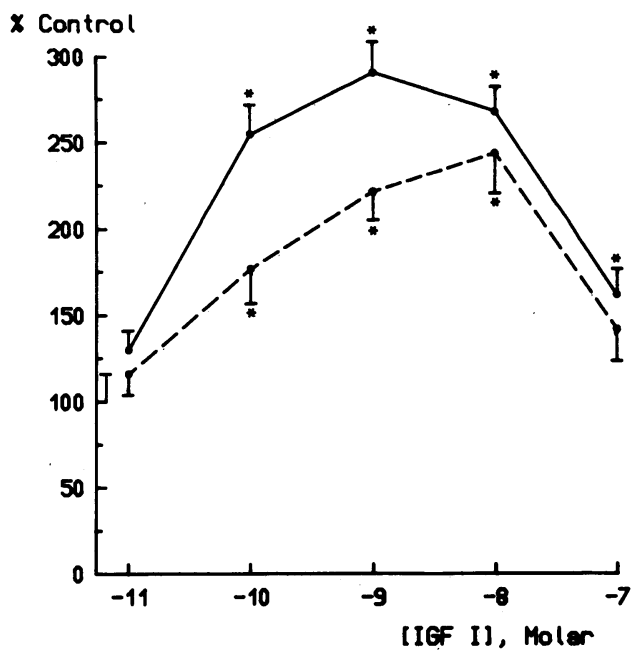

Figure 1. Chemoattractant effect of IGF-I on unactivated and PHAactivated $T$ lymphocytes. $T$ cell migration was assayed with a modified 48-well Boyden chamber as described in materials and methods. $T$ cell migration was quantitated by counting the cells migrating beyond a certain depth, set to give a baseline migration under control conditions of $\sim 10$ cells. IGF-I concentrations in lower wells were $10^{-11}$ to $10^{-7} \mathrm{M}$. Lymphocyte migration is expressed as percent migration under control conditions (media without IGF-I), in which $100 \%$ of control migration was $10 \pm 1.7$ (mean $\pm \mathrm{SD}$ ) (unactivated) or 15.2 \pm 1.9 (PHA-activated) cells/hpf. Migration of both unactivated (dashed line) and PHA-activated cells (solid line) was markedly enhanced by IGF-I. Migration of unactivated cells peaked at $24.4 \pm 2.4$ cells/hpf ( $244 \pm 24 \%$ of control migration) at an IGF-I concentration of $10^{-8} \mathrm{M}$. PHA-activated cells demonstrated a one-log dose-response shift with migration peaking at $44.2 \pm 3.2$ cells/hpf $(291 \pm 21 \%$ of control migration) at an IGF-I concentration of $10^{-9} \mathrm{M}$. In each migration assay the migratory response decreased at high concentrations of IGF-I. *Significantly different from control conditions, $P$ $<0.01$.

tactic) or independent of the effect of a gradient (chemokinetic) (Fig. 3). The response of T cells to IGF-I was clearly greater when IGF-I was present below the filter only (i.e., gradient present). A significant chemokinetic effect was seen as well, in that cells showed significantly increased motility even when IGF-I was present in equal concentrations above and below the filter.

$\left[{ }^{3} \mathrm{H}\right] \mathrm{T}$ incorporation. IGF-I stimulated uptake of $\left[{ }^{3} \mathrm{H}\right] \mathrm{T}$ into resting $\mathrm{T}$ lymphocytes to a significantly greater extent $(\boldsymbol{P}$ $<.01$ ) than occurred in control cells, or in cells incubated with IL-2 alone (Table I). In both experiments control and IL-2 treated cells demonstrated low baseline levels of $\left[{ }^{3} \mathrm{H}\right] \mathrm{T}$ uptake, while IGF-I at $10^{-9} \mathrm{M}$ induced a three- to fourfold increase in $\left[{ }^{3} \mathrm{H}\right] \mathrm{T}$ uptake. Dose-response experiments in resting cells revealed that IGF-I was active in concentrations as low as $10^{-10}$ $M$, and peaked in activity at $10^{-9} \mathrm{M}$ (not shown). IL-2 FACS plots of cells stained with propidium iodide revealed an increase in the number of cells in the $G_{2}+M$ phases when resting cells were exposed to IGF-I (not shown). When the cells were activated with PHA and then incubated with IGF-I, the response was again significantly greater than with control (cells activated with PHA alone). As expected, IL-2 at $100 \mathrm{U} / \mathrm{ml}$ significantly enhanced $\left[{ }^{3} \mathrm{H}\right] \mathrm{T}$ uptake in PHA activated T cells. There was no difference in $\left[{ }^{3} \mathrm{H}\right] \mathrm{T}$ uptake between IL-2 and IGF-I treated PHA-activated cells.

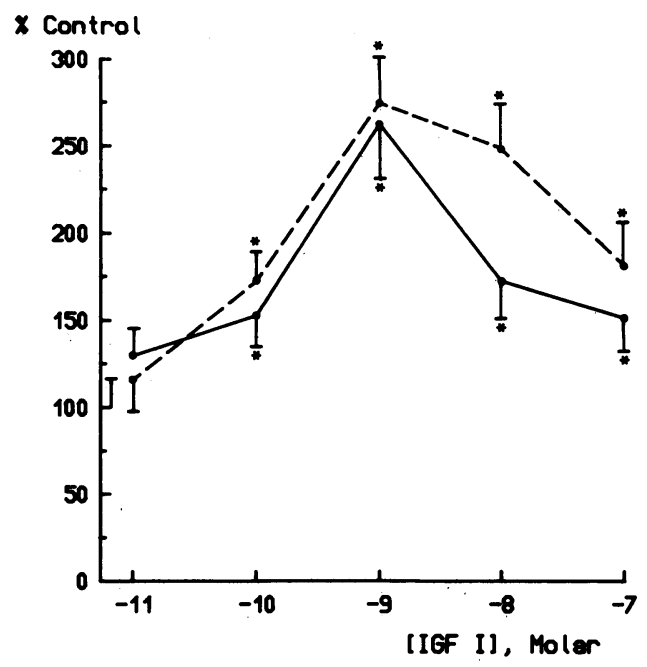

Figure 2. Chemoattractant effect of IGF-I on PHA-activated T lymphocyte subsets. IGF-I concentrations were $10^{-11}$ to $10^{-7} \mathrm{M}$. Lymphocyte migration is expressed as percent migration under control conditions (media without IGF-I), in which $100 \%$ of control migration was $9.1 \pm 1.5$ (mean $\pm \mathrm{SD}$ ) (T4 subset) or $8.3 \pm 1.2$ (T8 subset) cells/hpf. The $T$ cell subsets incubated for $48 \mathrm{~h}$ with PHA demonstrated similar migratory responses to IGF-I; for the T4 subset (solid line) migration peaked at $263 \pm 20 \%$ and for the T8 subset (dashed line) at $275 \pm 18 \%$ of control migration, respectively. *Significantly different from control conditions, $P<0.01$.

\section{Characterization of the IGF-I receptor}

Competitive binding studies. Specific binding of IGF-I to both resting and PHA-activated cells was demonstrated. The resulting curvilinear Scatchard plot for PHA-activated cells is shown in Fig. 4 and for resting cells in Fig. 5. A representative competition assay comparing IGF-I binding to that of insulin is

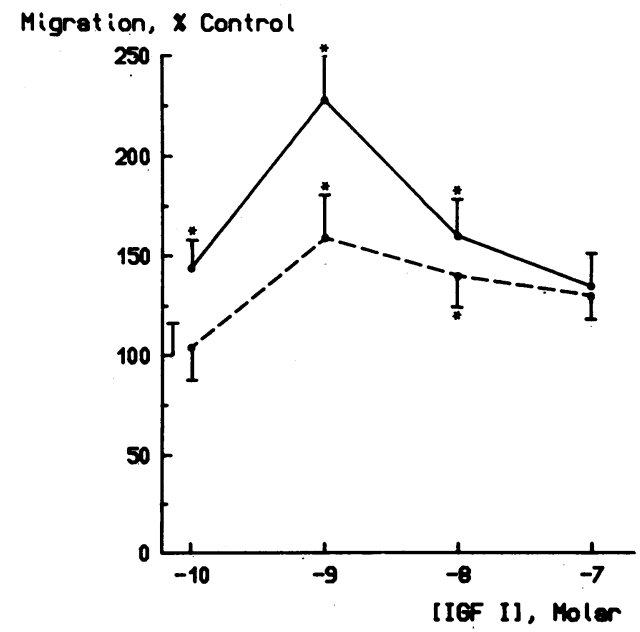

Figure 3. Chemoattractant effect of IGF-I on activated T cells: effect of a gradient. IGF-I concentrations were $10^{-10}$ to $10^{-7} \mathrm{M}$ in the lower chamber (concentration gradient present: solid line) or in both chambers (gradient absent: dashed line). Lymphocyte migration is expressed as percentage of control migration in media without IGF-I. Migration is clearly enhanced in the presence of a concentration gradient, peaking at $228 \pm 25 \%$ with $10^{-9} \mathrm{M}$ IGF-I; in the absence of a gradient migration peaked at $159 \pm 26 \%$. ${ }^{*}$ Significantly different from control conditions, $P<0.01$. 
Table I. Effect of IGF-I on $\left[{ }^{3} \mathrm{H}\right] T$ Incorporation by Resting or PHA-activated T Cells

\begin{tabular}{lcc}
\hline & \multicolumn{2}{c}{$\left[^{3} \mathrm{H}\right] \mathrm{T}$} \\
\cline { 2 - 3 } \multicolumn{1}{c}{ Sample } & Experiment 1 & Experiment 2 \\
\hline & \multicolumn{2}{c}{$c p m$} \\
Control (cells/media) & $161 \pm 15$ & $368 \pm 22$ \\
IGF-I (10 $\mathrm{M})$ & $721 \pm 59^{*}$ & $1,139 \pm 74^{*}$ \\
IL-2 $(100 \mathrm{U} / \mathrm{ml})$ & $165 \pm 30$ & $412 \pm 48$ \\
Control $(\mathrm{PHA} 2 \mu \mathrm{g} / \mathrm{ml})$ & $40,624 \pm 7,651$ & $163,096 \pm 9,839$ \\
PHA + IGF-I $\left(10^{-9} \mathrm{M}\right)$ & $85,298 \pm 2,886^{\ddagger}$ & $203,784 \pm 4,018^{\ddagger}$ \\
PHA + IL-2 $(100 \mathrm{U} / \mathrm{ml})$ & $123,923 \pm 16,616^{\ddagger}$ & $197,479 \pm 20,946^{\ddagger}$
\end{tabular}

IGF-I or IL-2 were added to human T cells in HL-1 media (containing amino acids, selenium, protein, iron, transferrin, but without insulin), and then distributed in $200-\mu$ l aliquots $\left(10^{6}\right.$ cells $\left./ \mathrm{ml}\right)$ into $96-$ well round-bottomed culture plates and incubated at $37^{\circ} \mathrm{C}$ and $5 \%$ $\mathrm{CO}_{2}$. Controls for resting lymphocytes contained cells and media only; those for activated cells contained PHA $(2 \mu \mathrm{g} / \mathrm{ml})$, cells and media. Cells were pulsed with $1 \mu \mathrm{Ci}$ of $\left[{ }^{3} \mathrm{H}\right] \mathrm{T}$. At $72 \mathrm{~h}$, cell nuclei were harvested and counted. Mean values from quadruplicate wells are presented. Results are expressed as counts per minute of radioactivity incorporated by $2 \times 10^{5}$ cells after $72 \mathrm{~h}$ of incubation. Resting cells exposed to IGF-I incorporated $\left[{ }^{3} \mathrm{H}\right] \mathrm{T}$ to a significantly greater degree than control cells or cells exposed to IL-2 $\left({ }^{*} P<0.01\right)$. PHAactivated cells exposed to IGF-I also incorporated $\left[{ }^{3} \mathrm{H}\right] \mathrm{T}$ to a significantly greater degree than control PHA-activated cells $\left({ }^{\ddagger} P<0.01\right)$ but not to a greater degree than IL-2 treated PHA-activated cells.

also shown in Fig. 5 (inset). Scatchard analysis (31) of competitive binding assays revealed an apparent $K_{\mathrm{d}}$ of $1.2 \pm 0.6 \times 10^{-10}$ $M$ determined for the steep portion of the curve for activated cells and $1.2 \pm 0.9 \times 10^{-10}$ for resting cells. For activated cells,

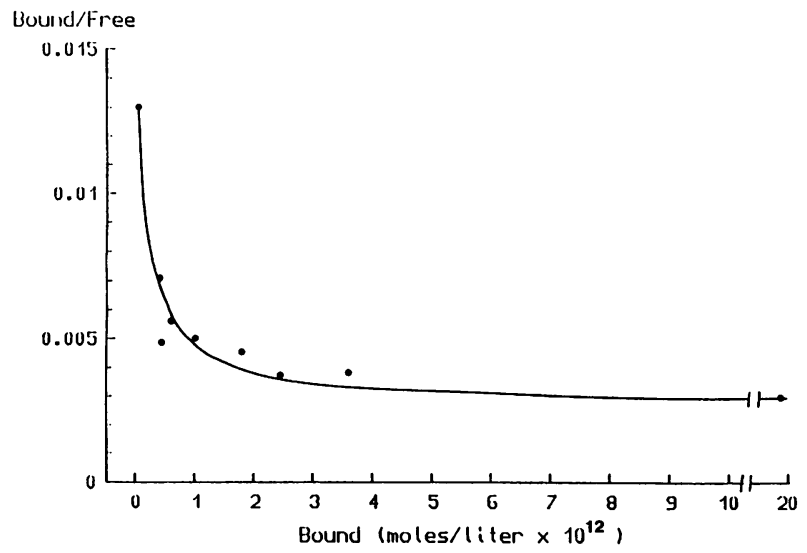

Figure 4. Representative Scatchard plot of ${ }^{125}$ I-IGF-I binding to PHA-activated human T lymphocytes. ${ }^{125}$ I-IGF-I $(100,000 \mathrm{cpm}$ per assay) was added in $20-\mu$ l aliquots to $20 \mu 1$ of unlabeled ligand $\left(10^{-11}\right.$ to $10^{-7} \mathrm{M}$ ) or to media alone. Human $\mathrm{T}$ lymphocytes were added at $10^{6}$ cells per $460-\mu \mathrm{l}$ aliquot yielding a final volume of $500 \mu \mathrm{l}$. After incubation at $15^{\circ} \mathrm{C}$ for $60 \mathrm{~min}$, the tubes were centrifuged and the cell pellet was resuspended and washed. Gamma counting of bound ${ }^{125}$ I-IGF-I was performed. Each point represents the mean of triplicate assays. Plots were reproducibly curvilinear. The apparent $K_{\mathrm{d}}$ for the receptor was $1.3 \times 10^{-10} \mathrm{M}$ and the calculated binding for activated cells was 390 high-affinity receptor sites per cell.

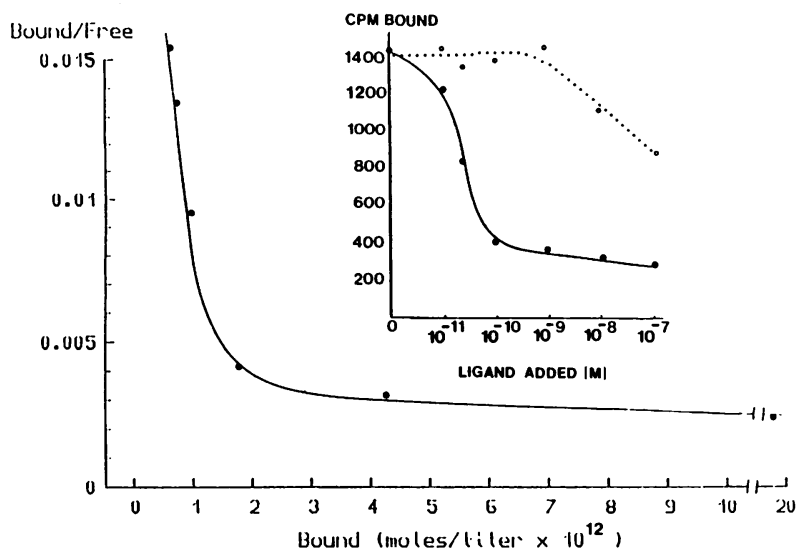

Figure 5. Representative Scatchard plot of ${ }^{125}$ I-IGF-I binding to resting (unactivated) human $T$ lymphocytes. The assays with resting cells were performed in the same manner as those with activated cells except that more cells $\left(10 \times 10^{6}\right.$ cells per point $)$ were required to demonstrate binding. Each point represents the mean of triplicate assays. Plots were reproducibly curvilinear. The apparent $K_{\mathrm{d}}$ for the receptor was $1.2 \times 10^{-10} \mathrm{M}$ and the calculated binding for resting cells was 51 high-affinity receptor sites per cell. (Inset) A competition assay comparing displacement of ${ }^{125} \mathrm{I}$-IGF-I by increasing concentrations of unlabeled insulin (dashed line) or IGF-I (solid line). There was no significant displacement of ${ }^{125}$ I-IGF-I until high concentrations of insulin $\left(10^{-7} \mathrm{M}\right)$ were reached.

$330 \pm 90$ receptor sites were calculated per cell. There was less specific binding of IGF-I to resting T cells $(45 \pm 9$ binding sites per cell) but binding could be clearly demonstrated when cell concentration was increased 10 -fold $\left(10 \times 10^{6}\right.$ cells/aliquot $)$ (Fig. 5). Displacement of ${ }^{125}$ I-IGF-I by insulin from resting $\mathrm{T}$ cells could be demonstrated only with very high doses of insulin.

Affinity cross-linking. Utilizing DSS, ${ }^{125}$ I-IGF-I was effectively cross-linked to 48-h PHA-activated as well as to resting $\mathrm{T}$ cells (Fig. 6). Under nonreducing conditions, the major labeled species was a 360,000-mol wt moiety compatible in size with the IGF-I receptor (32). Polypeptides corresponding to 270,000 and $135,000 \mathrm{~mol}$ wt (after subtraction of the 7,500 mol wt contributed by the cross-linked ${ }^{125}$ I-IGF-I) were identified under reducing conditions. Excess unlabeled IGF-I effectively prevented the cross-linking of radiolabeled ligand in each case. Although the 270,000-mol wt band corresponds roughly in size with the insulin-like growth factor II (IGF-II) receptor under reducing conditions, there was no band compatible with the IGF-II receptor under nonreducing conditions. We therefore believe that the $270,000 \mathrm{~mol} w \mathrm{w}$ species most likely represents $\alpha$ chain- $\alpha$ chain cross-linking, as previously described (33). The $135,000-\mathrm{mol} \mathrm{wt}$ band corresponds in size to the $\alpha$ chain of the IGF-I receptor. We obtained labeling of a band of identical size by cross-linking ${ }^{125}$ I-IGF-I to HuT 78 cells (data not shown).

\section{Discussion}

We investigated the effect of recombinant human IGF-I on cellular growth and motility of purified human blood $\mathrm{T}$ lymphocytes. We found IGF-I to be chemotactic and chemokinetic for both resting and activated human $\mathrm{T}$ lymphocytes. Chemotactic responsiveness was identical in $\mathrm{CD}^{+}$and $\mathrm{CD} 8^{+}$ 


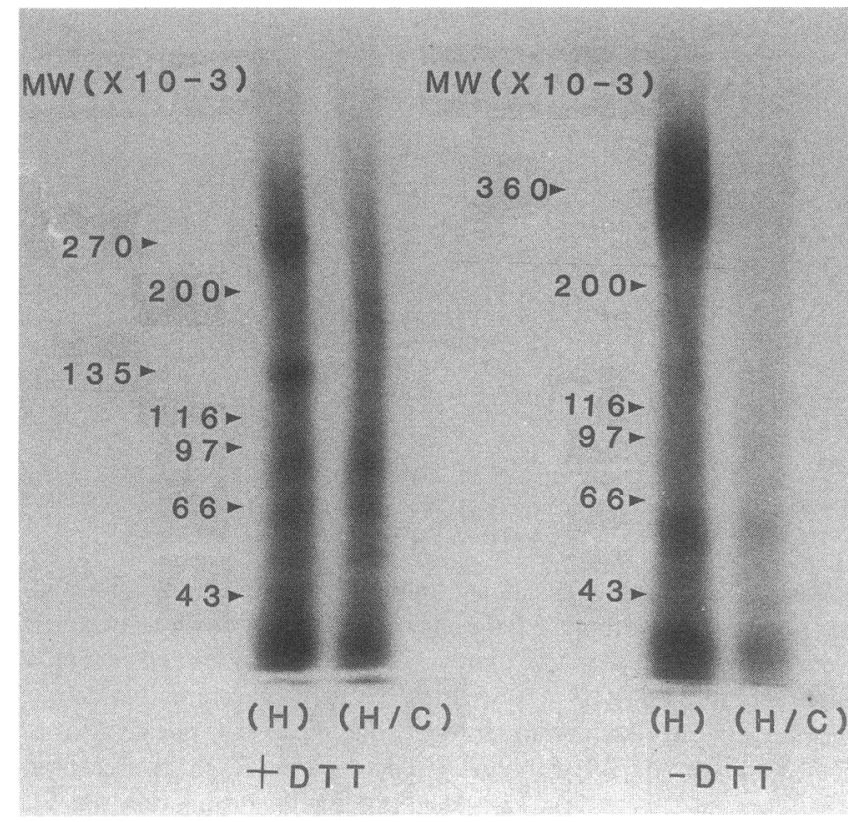

Figure 6. Affinity cross-linking of ${ }^{125} \mathrm{I}-\mathrm{IGF}-\mathrm{I}$ to PHA-activated T lymphocyte membranes. ${ }^{125} \mathrm{I}-\mathrm{IGF}-\mathrm{I}$ was bound to $\mathrm{T}$ cell membranes $\left(25 \times 10^{6}\right.$ cells per assay) under high-affinity conditions using disuccinimidyl suberate (DSS) as a cross-linking agent. SDS-polyacrylamide gel electrophoresis (3-10\% gradient gel) was performed followed by autoradiography. Samples were analyzed in the absence $(H)$ or presence $(H / C)$ of excess unlabeled IGF-I $\left(10^{-7} \mathrm{M}\right)$. Reduction of disulfide bonds with dithiothreitol $(+D T T)($ left) revealed complexes of 270,000 and $135,000 \mathrm{~mol} \mathrm{wt}$; the former represents $\alpha-\alpha$ cross-linking and the latter complex the $\alpha$ (ligand-binding) subunit of the IGF-I receptor. Under nonreducing conditions (right), the labeled species appears at $360,000 \mathrm{~mol} \mathrm{wt}$ and represents the intact IGF-I receptor. MW, molecular weight.

cells. IGF-I also stimulated increased uptake of $\left[{ }^{3} \mathrm{H}\right] \mathrm{T}$ into T lymphocytes cultured in a defined medium containing no growth factors such as insulin. This effect was demonstrated in both resting and PHA-activated T cells. The lack of increased thymidine incorporation seen in resting cells treated with IL-2 $(100 \mathrm{U} / \mathrm{ml})$ suggests that these cells were indeed in a resting state, and that entry of cells into the cell cycle was induced by IGF-I alone. The effect of IGF-I on PHA-activated cells was equivalent to that seen with IL-2. Flow cytometric analysis was utilized to confirm the effects of IGF-I on $\left.{ }^{3} \mathrm{H}\right] \mathrm{T}$ incorporation. Dose response analysis suggested that IGF-I induced cellular motility and entry into the cell cycle at doses consistent with action on a high affinity IGF-I receptor.

We then investigated whether the effects of IGF-I on purified $T$ cells might be mediated by the receptor for IGF-I. We have shown that IGF-I binds specifically to both resting and activated $T$ lymphocytes. Scatchard analysis for IGF-I binding revealed a $K_{d}$ similar to that found in other tissues $\left(1.2 \times 10^{-10}\right.$ $M)$. Finally, we have demonstrated the presence of the receptor on the surfaces of both resting and activated purified $T$ cells and on a malignant $T$ cell line by affinity cross-linking.

The molecular mechanisms of leukocyte chemotaxis are complex and are reviewed elsewhere (34). Cell locomotion is dependent upon complex cytoskeletal changes. IGF-I has been shown to effect reorganization of the cytoskeleton in a human squamous cell line (35), suggesting that it might be a growth factor capable of inducing cell motility. The effect of IGF-I upon lymphocyte motility has not been previously demonstrated, although other growth factors including IL-1 $(16,17)$, IL-2 (18), and insulin (20) have recently been shown to be chemotactic for either activated (IL-2) or both resting and activated (IL-1, insulin) $\mathrm{T}$ cells. We believe that the effect of IGF-I upon cell motility is receptor-mediated. It is possible that a nonspecific growth factor effect not mediated through receptor binding is responsible for the results we obtained. We have demonstrated that IGF-I is chemotactic for resting and activated human $T$ lymphocytes with a half-maximal concentration consistent with the $K_{\mathrm{d}}$ of the receptor, providing evidence that the effect shown is mediated via high-affinity IGF-I receptors. In addition, the gradient-enhanced motility (chemotaxis) and high-dose inhibition demonstrated resemble that seen with insulin (20), IL-2 (18), and with other receptor-mediated chemotaxis models such as $\mathrm{N}$-formylated-methionyl peptides for neutrophils $(36,37)$ and platelet-derived growth factor for neutrophils and monocytes $(38,39)$. However, the precise mechanism through which IGF-I enhances $\mathrm{T}$ cell motility is unclear.

Insulin receptors are not present on resting $T$ cells, but are inducible by mitogen activation $(21-23,40)$. Krug et al. (21) demonstrated about 350 insulin molecules bound per transformed (activated) human lymphocyte with virtually no specific receptors for insulin on resting peripheral lymphocytes. Helderman et al. (23) found the lymphocyte insulin receptor to be a universal marker for lymphocyte activation. We have previously shown that insulin is chemotactic for resting as well as activated $T$ cells, but that there is a two-log leftward dose response shift after PHA activation. Because of the structural, functional and antigenic similarities of the insulin and IGF-I receptors, we suggested that IGF-I receptors might mediate the chemotactic effect of insulin on resting cells (20). Evidence for the presence of IGF-I receptors on the surface of resting $T$ cells now further supports this hypothesis. Others have determined that insulin at high doses may compete to occupy IGF-I receptors $(13,24)$ and it has been proposed that the major mitogenic actions of insulin result from its binding to the IGF-I receptor rather than to the insulin receptor itself (41). IGF-I is chemotactic for both $\mathrm{CD}^{+}$and $\mathrm{CD}^{+} \mathrm{T}$ cells, similar to the identical response of these subsets to insulin (20). This is in contradistinction to IL-2, which is chemotactic only for $\mathrm{CD}^{+}$ $\mathrm{T}$ cells (18).

Mitogenic effects of IGF-I have been demonstrated upon IM-9 lymphocytes, a lymphocytoblastoid B cell line (42), and other cell types as well. We have found IGF-I to initiate entry of resting cells into the cell cycle, as well as increasing the $\left[{ }^{3} \mathrm{H}\right] \mathrm{T}$ incorporation of mitogen-activated cells. The growth promoting activity of IGF-I for mitogen-activated cells was similar to that seen with IL-2, suggesting a possible mechanism for IGF-I action in these cells, i.e., stimulation of production of IL-2. This possibility is under study in our laboratory. That this mechanism is not responsible for the cell cycle entry seen in resting cells is suggested by the fact that IL-2 alone did not enhance $\left[{ }^{3} \mathrm{H}\right] \mathrm{T}$ incorporation into resting cells in our assay (Table I). A recent study (43) reported no effect of IGF-I (at doses similar to the ones which we employed) on IL-2 production, nor on antigen-driven proliferation as measured by $\left[{ }^{3} \mathrm{H}\right] \mathrm{T}$ incorporation. However, since our experiments and experimental conditions were different (i.e., different media, no antigen, different assay), we cannot speculate on the reasons for 
their negative results. Similarly, suppressive effects of IGF-I upon IL-2-induced lymphocyte proliferation have been demonstrated (44); we examined the effect of IGF-I and IL-2 separately in PHA-activated cells.

Evidence for presence of the IGF-I receptor on resting $T$ cells by competitive binding and affinity cross-linking provides a basis for its behavior as a competence factor. These data suggest that IGF-I produced locally in tissues such as thymus (6) or inflammatory sites might affect the growth and function of IGF-I receptor-bearing T lymphocytes. IGF-I is vital to normal growth. A defect in IGF-I secretion during puberty prohibits growth acceleration; this defect is exemplified in African pygmies (45). Low IGF-I levels also occur in Laron dwarfism (46) and in malnutrition $(47,48)$. However, the extent of the biologic importance of IGF-I may not yet be realized. In situ hybridization histochemistry studies suggest ubiquitous IGF synthesis with fibroblasts and mesenchymal cells within connective tissues as predominant sites (6). The IGF-I receptor is found in numerous tissues as well and the mitogenic actions of IGF-I upon multiple tissues $(1,3)$ support a more extensive role for this ligand-receptor system. In addition, fibroblasts both synthesize IGF-I $(4,49,50)$ and bear IGF-I receptors on their surfaces $(51,52)$; the cellular production of "somatomedin-like peptides" has been suggested as an example of the autocrine model of growth regulation (53). Because $\mathrm{T}$ lymphocytes are frequently involved with fibrotic tissue reactions the link between the chemotactic and growth factor activity of IGF-I may be important in the recruitment to and activation of effector lymphocytes at sites of fibroblast activation.

The chemotactic and mitogenic phenomena, which we have determined, prompted us to pursue more definitive proof of the IGF-I receptor on the surface of $T$ cells. We demonstrated competitive binding of IGF-I on the surfaces of both resting and activated $T$ cells and analyzed the results by the method of Scatchard (31). The resultant curvilinear plot could be interpreted as representative of a heterogenous population of receptors, i.e., high and low affinity receptors. Other possibilities such as negative cooperativity (54) or tighter binding of labeled IGF-I than of the unlabeled ligand (55) might be considered. Both linear $(9,56)$ and curvilinear $(57,58)$ plots have been reported with IGF-I binding in other human tissue types. Our results demonstrate that IGF-I binds specifically to the surface of $T$ lymphocytes. In addition, a cold competition assay was performed comparing the relative abilities of unlabeled insulin and IGF-I to displace ${ }^{125}$ I-IGF-I from resting T cells; insulin binding was demonstrated only with very high doses of insulin. We believe that this provides a compelling argument for IGF-I binding to resting $\mathrm{T}$ cells. It is difficult to be absolutely certain that our results represent a small amount of high-affinity IGF-I receptors on all of the cells; possibly a small subpopulation of cells has a larger number of receptors. Use of the fluorescent activated cell sorter enabled us to be certain that the cells were at least $95 \% \mathrm{CD} 3+$. The concentration of ${ }^{125}$ I-IGF-I used in our cross-linking assays was low enough to exclude the possibility of IGF-I binding to insulin receptors which are present on activated $T$ cells. Affinity cross-linking has been utilized in characterizing the quaternary structure of protein oligomers $(59,60)$ including the insulin $(28,29)$ and IGF-I $(26,61)$ receptors. We found the size of the IGF-I receptor complex and its binding subunit to be compatible with that found in other tissues $(26,62-64)$.
We conclude that IGF-I is chemotactic and mitogenic for both resting and activated human $\mathrm{T}$ cells in vitro. The IGF-I receptor that we have demonstrated to be present on the surface of $\mathrm{T}$ cells likely mediates these phenomena.

\section{Acknowledgments}

The authors would like to express appreciation to William Cruikshank for useful discussion and Chris Scannell for expert technical assistance.

This work was supported by National Research Service Award HL-07035-12 from the United States Public Health Service (Dr. Tapson), grant HL-017819 from the National Institutes of Health (Dr. Berman), a Feasibility Award from the American Diabetes Association (Dr. Berman), a Career Investigator Award from the American Lung Association (Dr. Center), and HL-19717 from the National Institutes of Health (Drs. Center and Berman). Marianne Boni-Schnetzler is a recipient of a postdoctoral fellowship from the Juvenile Diabetes Foundation. Dr. Pilch is a recipient of a research career development award from the United States Public Health Service.

\section{References}

1. Froesch, E. R., C. Schmidt, J. Schwander, and J. Zapf. 1985. Actions of insulin-like growth factors. Annu. Rev. Physiol. 47:443-467.

2. Rechler, M. M., H. J. Eisen, O. Z. Higa, S. P. Nissley, A. C Moses, E. E. Schilling, I. Fennoy, C. B. Bruni, L. S. Phillips, and K. L. Baird. 1979. Characterization of a somatomedin (insulin-like growth factor) synthesized by fetal rat liver organ cultures. J. Biol. Chem. 254:7942-7950.

3. Underwood, L. E., and A. J. D'Ercole. 1984. Insulin and insulin-like growth factors/somatomedins in fetal and neonatal development. Clin. Endocrinol. Metab. 13:69-89.

4. Clemmons, D. R., L. E. Underwood, and J. J. Van Wyk. 1981. Hormonal control of immunoreactive somatomedin production by cultured human fibroblasts. J. Clin. Invest. 67:10-19.

5. Zapf, J., C. H. Schmidt, and E. R. Froesch. 1984. Biological and immunological properties of insulin-like growth factors (IGF) I and II. Clin. Endocrinol. Metab. 13:3-30.

6. Han, V. K. M., A. J. D'Ercole, and P. K. Lund. 1987. Cellular localization of somatomedin (insulin-like growth factor) messenger RNA in the human fetus. Science (Wash. DC). 236:193-197.

7. Marshall, R. N., L. E. Underwood, S. J. Voina, D. B. Foushee, and J. J. Van Wyk. 1974. Characterization of the insulin and somatomedin-C receptors in human placental membranes. J. Clin. Endocrinol. Metab. 39:283-292.

8. Rechler, M. M., S. P. Nissley, J. M. Podskalny, A. C. Moses, and L. Frykland. 1977. Identification of receptor for somatomedin-like polypeptides in human fibroblasts. J. Clin. Endocrinol. Metab. 44:820-831.

9. Burgess, S. K., S. Jacobs, P. Cuatrecasas, and N. Sahyoun. 1987. Characterization of a neuronal subtype of insulin-like growth factor I receptor. J. Biol. Chem. 262:1618-1622.

10. Beguinot, F., C. R. Kahn, A. C. Moses, and R. J. Smith. 1985. Distinct biologically active receptors for insulin, insulin-like growth factor I, and insulin-like growth factor II in cultured skeletal muscle cells. J. Biol. Chem. 260:15892-15898.

11. Lin, T., J. Haskell, N. Vinson, and L. Terracio. 1986. Characterization of insulin and insulin-like growth factor I receptors of purified Leydig cells and their role in steroidogenesis in primary culture: $A$ comparative study. Endocrinology. 119:1641-1647.

12. Thorsson, A. V., and R. L. Hintz. 1977. Specific ${ }^{125}$ I-somatomedin receptors on circulating human mononuclear cells. Biochem. Biophys. Res. Commun. 74:1566-1573.

13. Rosenfeld, R. G., and R. L. Hintz. 1980. Characterization of a specific receptor for somatomedin-C (SM-C) on cultured human lymphocytes: evidence that SM-C modulates homologous receptor concentrations. Endocrinology. 107:1841-1848. 
14. Guler, H., J. Zapf, and E. R. Froesch. 1987. Short-term metabolic effects of recombinant human insulin-like growth factor in healthy adults. N. Engl. J. Med. 317:137-140.

15. Wilkinson, P. C. 1982. The locomotion of leucocytes: definitions and descriptions. In Chemotaxis and Inflammation. P. C. Wilkinson, editor. Churchill Livingstone, Inc., New York. 1-25.

16. Miossec P., C. Yu, and M. Ziff. 1984. Lymphocyte chemotactic activity of human interleukin 1. J. Immunol. 133:2007-2111.

17. Hunninghake, G. W., A. J. Glazier, M. M. Monick, and C. A. Dinarello. 1987. Interleukin-1 is a chemotactic factor for human $\mathrm{T}$ lymphocytes. Am. Rev. Respir. Dis. 135:66-71.

18. Kornfeld, H., J. S. Berman, D. J. Beer, and D. M. Center. 1985. Induction of human T lymphocyte motility by interleukin 2. J. Immunol. 134:3887-3890.

19. Russell, R. J., P. C. Wilkinson, F. Sless and D. M. V. Parrott 1975. Chemotaxis of lymphoblasts. Nature (Lond.). 256:646-648.

20. Berman, J. S., and D. M. Center. 1987. Chemotactic activity of porcine insulin for human $\mathrm{T}$ lymphocytes in vitro. J. Immunol. 138:2100-2103.

21. Krug, U., F. Krug, and P. Cuatrecasas. 1972. Emergence of insulin receptors on human lymphocytes during in vitro transformation. Proc. Natl. Acad. Sci. USA 69:2604-2608.

22. Helderman, J. H., and T. B. Strom. 1978. Specific insulin binding site on $\mathrm{T}$ and $\mathrm{B}$ lymphocytes as a marker of cell activation. Nature (Lond.). 274:62-63.

23. Helderman, J. H., T. C. Reynolds, and T. B. Strom. 1978. The insulin receptor as a universal marker of activated lymphocytes. Eur. J. Immunol. 8:589-595.

24. Zapf, J. E., E. Rinderknecht, R. E. Humbel, and E. R. Froesch. 1978. Non-suppressible insulin-like activity (NSILA) from human serum: recent accomplishments and their physiological implications. Metab. Clin. Exp. 27:1803-1828.

25. Julius, M. H., E. Simpson, and L. A. Herzenberg. 1973. A rapid method for the isolation of functional thymus-derived murine lymphocytes. Eur. J. Immunol. 3:645-649.

26. Boyden, S. 1962. The chemotactic effect of mixtures of antibody and antigen on polymorphonuclear leukocytes. J. Exp. Med. 115:453-466.

27. Zigmond, S. H., and J. G. Hirsch. 1973. Leukocyte locomotion and chemotaxis: New methods for evaluation and demonstration of cell-derived chemotactic factor. J. Exp. Med. 137:387-410.

28. Pilch, P. F., and M. P. Czech. 1979. Interaction of cross-linking agents with the insulin effector system of isolated fat cells. J. Biol. Chem. 254:3375-3381.

29. Pilch, P. F., and M. P. Czech. 1980. The subunit structure of the high affinity insulin receptor. J. Biol. Chem. 255:1722-1731.

30. Gootenberg, J. E., F. W. Ruscetti, J. W. Mier, A. Gadzar, and R. C. Gallo. 1981. Human cutaneous T cell lymphoma and leukemia cell lines produce and respond to T cell growth factor. J. Exp. Med. 154:1403-1418.

31. Scatchard, G. 1949. The attraction of proteins for small molecules and ions. Ann. N.Y. Acad. Sci. 51:660-672.

32. Kasuga, M., E. E. Van Obberghen, S. P. Nissley, and M. M. Rechler. 1981. Demonstration of two subtypes of insulin-like growth factor receptor by affinity cross-linking. J. Biol. Chem. 256:53055308.

33. Pilch, P. F., T. O'Hare, J. Rubin, and M. Boni-Schnetzler. 1986. The ligand binding subunit of the insulin-like growth factor I receptor has properties of a peripheral membrane protein. Biochem. Biophys. Res. Commun. 136:45-50.

34. Snyderman, R., and E. J. Goetzl. 1981. Molecular and cellular mechanisms of leukocyte chemotaxis. Science (Wash. DC). 213:830837.

35. Kadowaki, T., S. Koyasu, E. Nishida, S. Hikoichi, T. Fumimaro, I. Yahara, and M. Kasuga. 1986. Insulin-like growth factors, insulin, and epidermal growth factor cause rapid cytoskeletal reorganization in KB cells. J. Biol. Chem. 261:16141-16147.

36. Snyderman, R., C. D. Smith, and M. W. Verghese. 1986. Model for leukocyte regulation by chemoattractant receptors: Roles of a guanine nucleotide regulatory protein and polyphosphoinositide metabolism. J. Leukocyte Biol. 40:785-800.

37. Naccache, P. H., and R. I. Sha'afi. 1986. Neutrophil activation, polyphosphoinositide hydrolysis, and the guanine nucleotide regulatory proteins. In New Insights into Cell and Membrane Transport Processes. G. Poste and S. T. Crooke, editors. Plenum Press, New York. 175-192.

38. Williams, L. T., H. N. Antoniades, and E. J. Goetzl. 1983. Platelet-derived growth factor stimulates mouse 3T3 cell mitogenesis and leukocyte chemotaxis through different structural determinants. $J$. Clin. Invest. 72:1759-1763.

39. Deuel, T. F., R. M. Senior, J. S. Huang, and G. L. Griffin. 1982. Chemotaxis of monocytes and neutrophils to platelet-derived growth factor. J. Clin. Invest. 69:1046-1049.

40. Helderman, J. H., and T. B. Strom. 1977. Emergence of insulin receptors upon alloimmune $\mathrm{T}$ cells in the rat. J. Clin. Invest. 59:338344.

41. King, G. L., C. R. Kahn, M. M. Rechler, and S. P. Nissley. 1980. Direct demonstration of separate receptors for growth and metabolic activities of insulin and multiplication-stimulating activity (an insulin-like growth factor) using antibodies to the insulin receptor. $J$. Clin. Invest. 66:130-140.

42. Schimpff, R. M., A. M. Repellin, A. Salvatoni, G. ThieriotPrevost, and P. Chatelain. 1983. Effect of purified somatomedins on thymidine incorporation into lectin-activated human lymphocytes. Acta Endocrinol. 102:21-26.

43. Herzberg, V. L., and K. A. Smith. 1987. T cell growth without serum. J. Immunol. 139:998-1004.

44. Hunt, P., and D. D. Eardly. 1986. Suppressive effects of insulin and insulin-like growth factor (IGF-I) on immune responses. J. Immunol. 136:3994-3999.

45. Merimee, T. J., J. Zapf, B. Hewlett, and L. L. Cavalli-Sforza 1987. Insulin-like growth factors in pygmies. The role of puberty in determining final stature. N. Engl. J. Med. 316:906-911.

46. Laron, Z. Laron-type dwarfism (hereditary somatomedin deficiency): a review. 1984. Ergeb. Inn. Med. Kinderheilkd. 51:117-150.

47. Isley, W. L., L. E. Underwood, and D. R. Clemmons. 1983. Dietary components that regulate serum somatomedin-C concentrations in humans. J. Clin. Invest. 71:175-182.

48. Underwood, L. E., D. R. Clemmons, M. Maes, A. J. D’Ercole, and J-M. Ketelslegers. 1986. Regulation of somatomedin-C/insulinlike growth factor I by nutrients. Horm. Res. 24:166-176.

49. Clemmons, D. R., and D. S. Shaw. 1983. Variables controlling somatomedin production by cultured human fibroblasts. J. Cell. Physiol. 115:137-142.

50. Clemmons, D. R., and D. S. Shaw. 1986. Purification and biologic properties of fibroblast somatomedin. J. Biol. Chem. 261:10293-10298.

51. Rosenfeld, R. G., and L. A. Dollar. 1982. Characterization of the somatomedin-C/insuling-like growth factor-I (Sm-C/IGF-I) receptor on cultured human fibroblast monolayers: regulation of receptor concentrations by Sm-C/IGF-I and insulin. J. Clin. Endocrinol. Metab. 55:434-440.

52. Rosenfeld, R. G., L. A. Dollar, and C. A. Conover. 1984 Density associated loss of functional receptors for somatomedin-C/insulin-like growth factor-I (Sm-C/IGF-I) on cultured human fibroblast monolayers. J. Cell. Physiol. 121:419-424.

53. Clemmons, D. R., and J. J. Van Wyk. 1985. Evidence for a functional role of endogenously produced somatomedin-like peptides in the regulation of DNA synthesis in cultured human fibroblasts and porcine smooth muscle cells. J. Clin. Invest. 75:1914-1918.

54. DeMeyts, P., and J. Roth. 1975. Cooperativity in ligand binding: A new graphic analysis. Biochem. Biophys. Res. Commun. 66:1118-1126.

55. Taylor, S. I. 1975. Binding of hormones to receptors. An alternative explanation of nonlinear Scatchard plots. Biochemistry. 14:2357-2361. 
56. Sara, V. R., K. Hall, M. Misaki, L. Fryklund, N. Christensen, and $\mathrm{L}$. Wetterberg. 1983. Ontogenesis of somatomedin and insulin receptors in human fetus. J. Clin. Invest. 71:1084-1094.

57. Izumi, T., M. Kasuga, T. Kadowaki, N. Hizuka, F. Takahu, and Y. Akanuma. 1986. Characteristics of human erythrocyte insulinlike growth factor receptors. J. Clin. Endocrinol. Metab. 62:12061212.

58. Baxter, R. C., and P. F. Williams. 1983. Reciprocal modulation of insulin and insulin-like growth factor receptor affinity by calcium. Biochem. Biophys. Res. Commun. 116:62-67.

59. Davies, G. E., and G. R. Stark. 1970. Use of dimethyl suberimidate, a cross-linking reagent, in studying the subunit structure of oligomeric proteins. Proc. Natl. Acad. Sci. USA. 66:651-656.

60. Peters, K. E., and F. M. Richards. 1977. Chemical cross-linking reagents and problems in studies of membrane structure. Annu. Rev. Biochem. 46:523-551.

61. Chernausek, S. D., S. Jacobs and J. J. Van Wyk. 1981. Structural similarities between human receptors for somatomedin $\mathrm{C}$ and insulin: analysis by affinity labeling. Biochemistry. 20:7350-7359.

62. Kasuga, M., E. E. Van Obberghen, S. P. Nissley, and M. M. Rechler. 1982. Structure of the insulin-like growth factor receptor in chicken embryo fibroblasts. Proc. Natl. Acad. Sci. USA 79:1864-1868.

63. Massague, J., and M. P. Czech. 1982. The subunit structures of two distinct receptors for insulin-like growth factor I and II and their relationship to the insulin receptor. J. Biol. Chem. 257:5038-5041.

64. Morgan, D. O., K. Jarnagin, and R. A. Roth. 1986. Purification and characterization of the receptor for insulin-like growth factor $\mathrm{I}$. Biochemistry. 25:5560-5564. 